\title{
PARASITOIDISM RATE AND LIFE TABLE PARAMETERS OF Aphytis diaspidis (HOWARD) (HYMENOPTERA: APHELINIDAE) AND Hemiberlesia lataniae (SIGNORET) (HEMIPTERA: DIASPIDIDAE)
}

\author{
Dennis Navea O. ${ }^{1}$, and Robinson Vargas M..$^{*}$
}

Latania scale, Hemiberlesia lataniae (Signoret), has become a major pest of avocado (Persea americana Mill.) in Chile and has reached high populations in the fruit because of limited natural control. The objective of this study was to identify the biological parameters of the parasitoid Aphytis diaspidis (Howard) as a control agent of latania scale. Postembryonic development, parasitoidism rate, and life table parameters of the parasitoid and scale were determined under laboratory conditions. Aphytis diaspidis postembryonic development and parasitoidism rate varied significantly when evaluated on distinct latania scale stages with the highest survival (56\%) occurring at the third scale stage, it also had the shortest development time between egg and adult (19.14 d) and the highest parasitoidism rate $(66 \%)$. The intrinsic growth rate $\left(\mathrm{r}_{\mathrm{m}}\right)$ was higher for $A$. diaspidis $\left(\mathrm{r}_{\mathrm{m}}=0.099\right)$ than latania scale $\left(\mathrm{r}_{\mathrm{m}}=0.068\right)$. These laboratory results demonstrated that $A$. diaspidis is an effective parasitoid for decreasing $H$. lataniae populations, especially in the third stage.

Key words: Postembryonic development, life tables, parasitoidism, biological control, white scale, avocado.

A vocado production, Persea americana Mill. (Lauraceae), for export is greatly limited by pests such as trips and scales that mainly develop on the fruit at a high density and decrease marketable volumes (López and Bermúdez, 2007; Vargas and Rodríguez, 2008; Rugman-Jones et al., 2009).

Scales belong to the Diaspididae family includes many species of important pests worldwide found in crops such as citrus, apple, pear, walnut, and ornamental trees (Claps et al., 2001; Mazzeo et al., 2001; Charles and Henderson, 2002; Apostolos et al., 2010). The most important diaspididae in Chile for avocado production is latania scale, Hemiberlesia lataniae (Signoret) (Hemiptera: Diaspididae), which colonizes the fruit and increases production costs by about $3 \%$ because it must be removed by brushing (Ripa and Larral, 2008). Chemical control is currently the most widely used against Diaspididae in avocado; however, insecticides allowed by buyer markets scarcely control this pest (López and Bermúdez, 2007).

The most important natural enemies of scales throughout the world are ectoparasitoids of the Aphytis genus (Hymenoptera: Aphelinidae) (Erler and Tunç, 2001; Japoshvili and Karaca, 2002; Murdoch et al., 2005). These parasitoids exert their regulatory action through oviposition and larval development in the scale's body and also by host-feeding in the immature stages.

${ }^{1}$ Instituto de Investigaciones Agropecuarias INIA, Casilla 3, La Cruz, Chile. "Corresponding author (rvargas@inia.cl).

Received: 20 January 2012.

Accepted: 7 May 2012.
Moreover, it is characterized by a high capacity to adapt to perturbed and intensely managed agroecosystems as in the case of fruit crops (Matsumoto et al., 2003; Rojas, 2005). General habit parasitoids, including many Aphytis species, do not require a high scale population density to establish themselves on plants since they move to new areas through aerial dispersal in search of alternative hosts when there is a scarcity of primary hosts (Rosen and De Bach, 1979).

Natural enemies associated with latania scale in Chile are the Rhyzobius lophanthae (Blaisdell) and Coccidophilus citricola Brèthes (Coleoptera: Coccinellidae) predators as well as the Aphytis chilensis Howard, A. melinus De Bach (Hymenoptera: Aphelinidae) and Signiphora aspidioti Ashmead (Hymenoptera: Signiphoridae) parasitoids (Ripa and Larral, 2008). Both types of natural enemies released in high densities can provoke about $40 \%$ mortality of the scale population (Ripa and Larral, 2008). However, in their natural state, they are unable to exert the needed regulatory action to prevent economic damage produced by scales when they are in the fruit thus making it necessary to incorporate natural enemies to the agroecosystem to efficiently regulate pest populations

Before incorporating a new species or increasing an existing species in an agroecosystem, its biological and ecological characteristics must be known so as to estimate their potential as natural enemies on the pests (Chi and Yang, 2003; Bernardo et al., 2005; Eliopoulos, 2006; Liu, 2007). This can be achieved by constructing life tables which show population parameters of a species such as survival, longevity, reproduction, and oviposition (Maia 
et al., 2000; Speight et al., 2000). Furthermore, the physiological and morphological characteristics of each host stage greatly influence the parasitoid's biological parameters, and these relationships must be studied to predict their effectiveness as a natural enemy and establish the appropriate release time (Bernal et al., 1999).

The specificity of parasitoids in controlling scales has been a characteristic that has been advantageous in Integrated Pest Management (IPM) programs in the United States and Europe and especially with parasitoids of the Aphytis genus (Apostolos et al., 2010). Both A. melinus and A. aonidiae control well Aonidiella aurantii Maskell and Quadraspidiotus perniciosus (Comstock) (Hemiptera: Diaspididae), respectively, and have achieved a 54\% level of parasitoidism (Mazzeo et al., 2001). Furthermore, parasitoids of the Aphytis genus cause a high degree of mortality because of their host-feeding, especially in scale immature stages (Collier, 1995).

Given the control potential that species of the Aphytis genus have on scales and the scarcity of natural enemies associated with latania scale in avocado, the objective of the present study was to identify the biological parameters of the parasitoid A. diaspidis (Howard) (Hymenoptera: Aphelinidae) and its host $H$. lataniae (Hemiptera: Diaspididae) under laboratory conditions.

\section{MATERIALS AND METHODS}

\section{Species under study}

Aphytis diaspidis (Howard) was evaluated as a potential parasitoid of the Diaspididae Hemiberlesia lataniae (Signoret). The specimens of A. diaspidis partenogenetic were initially collected in the field in January 2007 from the $Q$. perniciosus scale (Comstock) in an orchard located in Limache (32 $\left.59^{\prime} \mathrm{S}, 71^{\circ} 16^{\prime} \mathrm{W}\right)$, Chile. After this, H. lataniae was bred on butternut squash (Cucurbita moschata Duchesne) in the laboratories of the Instituto de Investigaciones Agropecuarias (INIA) La Cruz, Valparaíso Region and then employed as host for $A$. diaspidis. The laboratory breeding rooms were maintained at $26 \pm 2$ ${ }^{\circ} \mathrm{C}, 65 \pm 5 \% \mathrm{RH}, 14: 10 \mathrm{~h}$ (L:D) following the breeding techniques described by Rose (1990) and Matadha et al. (2004). Assays were carried out in the laboratories of INIA La Cruz between January 2006 and October 2007.

Nine-day-old $H$. lataniae individuals correspond to the first stage $\left(1^{\text {st }} S\right), 15-d-o l d$ to the second stage $\left(2^{\text {nd }} S\right)$, and 40 -d-old to the third stage $\left(3^{\text {rd }} \mathrm{S}\right)$ as pointed out by Blank et al. (2000). Each experimental unit consisted of a plastic ring $(2.5 \mathrm{~cm}$ diameter, $1 \mathrm{~cm}$ height) bonded with inert glue to the butternut squash surface infested with a known number of crawlers that were then exposed to parasitoid adults. Subsequently, the top of the rings were closed with muslin to prevent parasitoids escaping and allow ventilation. Parasitoids were collected on the second day of emergence and were not $>72 \mathrm{~h}$ old because parasitoids $<24$ h old have a low oviposition capacity (Heimpel et al.,
1997). In addition, bee honey was maintained permanently as complementary food to increase reproduction (Heimpel et al., 1997). Observations of the experiments were made every $24 \mathrm{~h}$ with a $40 \mathrm{X}$ stereoscopic microscope (Zeiss Stemi 2000, Göttingen, Germany).

\section{Parasitoidism rate}

The effect of $1^{\text {st }} S, 2^{\text {nd }} S$, and $3^{\text {rd }} S$ of latania scale on the $A$. diaspidis female parasitoidism rate was determined. In an experimental area for $6 \mathrm{~h}, 10$ individuals from each latania scale stage were added per female parasitoid and then oviposition of each female was recorded. One replicate corresponded to one A. diaspidis adult female, and 25 replicates for each stage of latania scale were carried out.

\section{Survival}

Survival of A. diaspidis and H. lataniae was determined.A gravid $A$. diaspidis female was placed in an experimental area with 10 scales from the $3^{\text {rd }} \mathrm{S}$ fed butternut squash. After $6 \mathrm{~h}$, the females were removed and 1egg/experimental area was left, which corresponded to one replicate; 25 replicates were carried out. When the parasitoid adults reached full development, they were left without food inside gelatin capsules to record their survival after emergence. For $H$. lataniae, a gravid female was placed inside an experimental area. One replicate corresponded to one gravid female, and a total of 25 replicates were carried out. Crawlers that emerged during the oviposition period were eliminated on a daily basis.

\section{Fecundity}

A gravid $H$. lataniae female was left in the experimental area with a feeding substrate of butternut squash; this corresponded to one replicate and a total of 25 replicates were performed during the study. Crawlers that emerged during the oviposition period were recorded and eliminated on a daily basis from the experimental areas until the death of the scale was observed. For the $A$. diaspidis parasitoid, each 48- to 72-h-old adult was placed in an experimental area containing 10 latania scales from the $3^{\text {rd }} \mathrm{S}$. One replicate consisted in one female adult and a total of 25 replicates were completed. Fecundity was recorded until the death of the parasitoid.

\section{Postembryonic development}

The potential to develop from egg to adult of A. diaspidis and $H$. lataniae was established. The study was conducted in gravid females of the parasitoid and each one was placed in an experimental area with 10 scales from the $3^{\text {rdd }} \mathrm{S}$. Females were eliminated $6 \mathrm{~h}$ after inoculation and only 1 egg per experimental area was left. One egg corresponded to one replicate and a total of 25 replicates were performed. For latania scale, an experimental area with a butternut squash substrate was employed and a crawler was left to be observed on a daily basis to record the duration of each stage. One crawler corresponded to 
one replicate and a total of 25 replicates were performed during the study.

\section{Life table parameters}

Data obtained from the above mentioned experiments for both species were employed to calculate these parameters.

The net reproduction rate $\left(\mathrm{R}_{0}\right)$, intrinsic growth rate $\left(r_{m}\right)$, finite growth rate $(\lambda)$, and generation time $(T)$, as defined by Birch (1948), were calculated with the Life Tables SAS program and Jackknife to calculate parameter variances (SAS Institute, 2007).

\section{Statistical analysis}

All data were subjected to Levene's test for homogeneity of variance. The parasitoidism rate and postembryonic development data were then analyzed with a one-way ANOVA followed by Tukey's multiple comparison test $(\mathrm{P}<0.05)$.

\section{RESULTS AND DISCUSSION}

\section{Influence of host stage on parasitoidism rate}

Aphytis diaspidis had the highest parasitoidism rate when exposed to the $3^{\text {rd }} \mathrm{S}$ of latania scale (Table 1$)$, but did not register parasitoidism with $1^{\text {st }} \mathrm{S}$ diaspidid individuals $(F=$ 135.687, $\mathrm{gl}=2, p=<0.0001)$. On the other hand, these results are consistent with Opp and Luck (1986), who reported that A. melinus and A. lingnanensis preferred the $3^{\text {rd }} \mathrm{S}$ of the Aonidiella aurantii scale to oviposite. The highest parasitoidism in the $3{ }^{\text {rd }} \mathrm{S}$ is not surprising since large hosts provide an immediate resource for parasitoid larval development (Liu, 2007). This allows pointing out that the success of biological control programs based on the use of Aphytis must consider their release in periods that coincide with the highest density of the $3^{\text {rd }} \mathrm{S}$ of latania scale in the field. Along with this, it is proposed that a future study consider the effect of temperature on parasitoidism because the highest percentage was obtained between 20 and $25^{\circ} \mathrm{C}$ in species such as Trichogramma turkentanika Meyer (Hymenoptera: Trichogrammatidae) (Hansen and Jensen, 2002). This could be a determining factor when it is released in the field in zones where the temperature could have an impact on a low or null reduction of the pest.

In addition, a high mortality percentage was observed associated with host-feeding on the $1^{\text {st }} \mathrm{S}$ and $2^{\text {nd }} \mathrm{S}$ of latania scale. On the one hand, this reveals that the feeding behavior of the parasitoid would help the control of immature stages in the field and, on the other hand, could increase the presence of the parasitoid since it contributes

Table 1. Aphytis diaspidis parasitoidism rate on distinct Hemiberlesia lataniae stages.

\begin{tabular}{lclcc}
\hline & & \multicolumn{4}{c}{ Stages of $H$. lataniae Mean \pm SEM } \\
\cline { 3 - 5 } & $\mathrm{n}$ & $1^{\text {st }} \mathrm{S}$ & $2^{\text {nd }} \mathrm{S}$ & $3^{\text {rd }} \mathrm{S}$ \\
\hline A. diaspidis & 25 & $0 \pm 0 \mathrm{a}^{*}$ & $0.08 \pm 0.27 \mathrm{a}$ & $6.56 \pm 2.78 \mathrm{~b}$ \\
\hline
\end{tabular}

"Mean on the same row with different letter differs according to Tukey Test $(\mathrm{P} \leq 0.05)$; SEM: standard error of the mean. to increased egg production (Giron et al., 2004; Rivero and West, 2005). Similarly, Burger et al. (2004) determined an increase in the life expectancy of the Encarsia formosa Gahan (Hymenoptera: Aphelinidae), parasitoid because of this feeding strategy, which also increased the number of eggs when fed honey. Heimpel and Rosenheim (1995) point out that host-feeding is a very good strategy in young individuals or in species with low egg production. Giron et al. (2002) point out that sucrose and trialose in the host would be mainly responsible for the increase in female longevity. This behavior would not have any significant effect on males because they would obtain their sources of food in less time than the females (Rivero and West, 2005). Further laboratory and field studies would be relevant to determine the importance of host-feeding on reducing scale populations.

\section{Survival}

Aphytis diaspidis and $H$. lataniae females showed gradual mortality over time, which can be attributed to death by natural aging of the individuals (Figures 1 and 2).

The two species demonstrated a type I survival curve, i.e., mortality was concentrated in older individuals. The A. diaspidis individuals started to die from day 14 until day 24 and showed a sharp drop on day 21. Meanwhile, $H$. lataniae specimens started to die on day 10; however, there

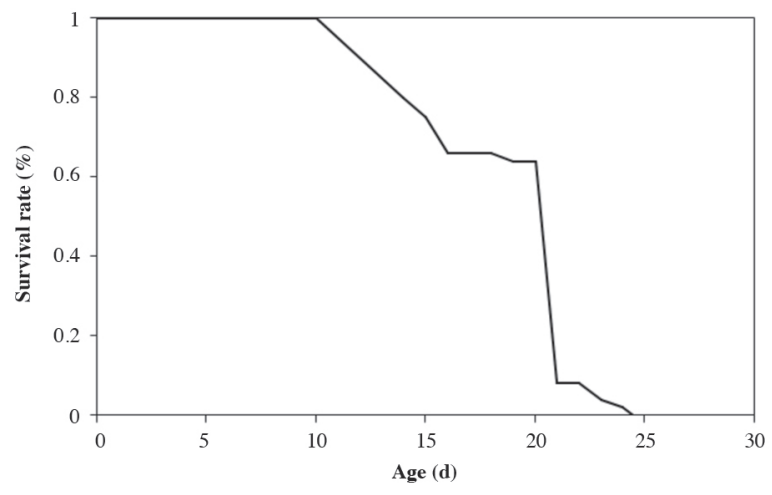

Figure 1. Aphytis diaspidis female survival curve.

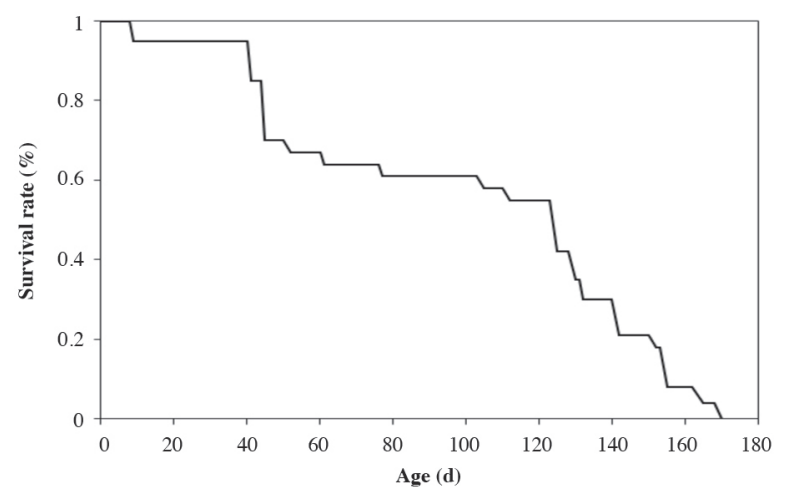

Figure 2. Hemiberlesia lataniae female survival curve. 
is a sharp decrease on day 56 that continues gradually until day 169. Latania scale manages to reach a survival rate about seven times higher than the A.diaspidis parasitoid and determines the time needed in the field between releases. In the ectoparasitic species Mastrus ridibundus (Gravenhorst) (Hymenoptera: Ichneumonidae), higher longevity was observed in females that were fed than those that received little food (Bezemer et al., 2005). It has also been determined in the Eupelmus vuilletti (Crawford) (Hymenoptera: Eupelmidae) species that host-feeding increases both longevity and egg production (Giron et al., 2004). As a result, a greater availability of females could occur over time when there is food, but this is not necessarily associated with an increase in the parasitoidism rate.

\section{Fecundity}

The highest fecundity value recorded for latania scale occurred between days 46 and 58 (Figure 3), unlike $A$. diaspidis fed on the $3^{\text {rd }} \mathrm{S}$ of latania scale that had maximum values on days 20 and 21 (Figure 4). This study does not analyze the increase in fecundity as related to female size or host nutritional status, which could influence an increase in the oviposition period. The increase in fecundity is determined by the quantity of lipids that

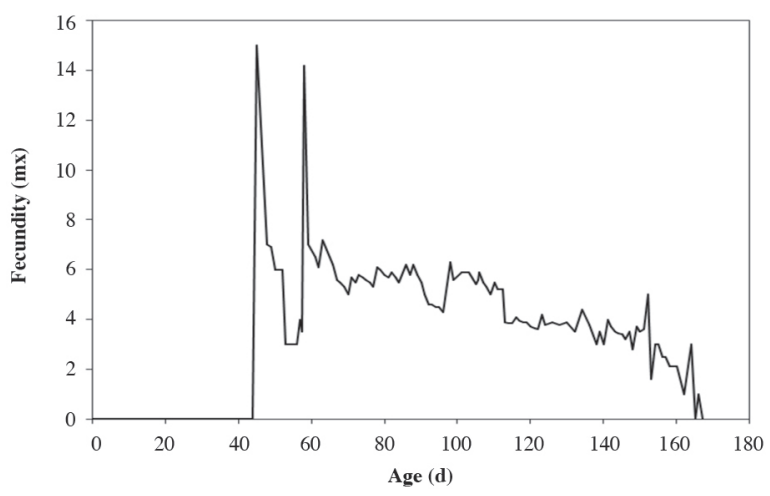

Figure 3. Female fecundity curve of Hemiberlesia lataniae fed butternut squash (Cucurbita moschata).

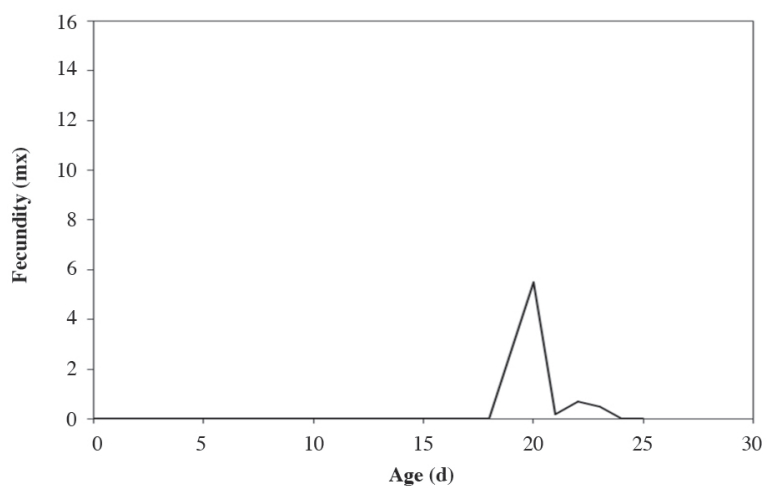

Figure 4. Female fecundity curve of Aphytis diaspidis fed $3^{\text {rd }} \mathrm{S}$ of Hemiberlesia lataniae. promote egg production (Giron et al., 2004). Parasitoid females use a great quantity of reserved lipids during the first $24 \mathrm{~h}$ of life, which could be a limiting factor mainly in the smaller females (Rivero and West, 2002). In some species, larger females produce a higher number of eggs and a higher egg maturation rate (Bezemer et al., 2005). In A. melinus fed with Aspidiotus nerii, it was determined that an increase in reproductive activity would also occur with an external food supply with sugars (Heimpel et al., 1997). This is how sugars, complemented with the supply of pollen, increase longevity and fecundity in species of the Trichogramma genus (Zhang et al., 2004). This effect is common in predatory mites of the Phytoseiidae family such as Typhlodromus pyri where some Brassicaceae species have increased female longevity and fecundity (Bermúdez et al., 2010). Similarly, the food's nutritional value plays an important role in assisting flight and increasing their search capacity (Rivero and West, 2002; Wanner et al., 2006). That is why plant species with flowers providing nectar are very important under field conditions.

\section{Postembryonic development}

The A. diaspidis parasitoid fed with the $3^{\text {rd }} \mathrm{S}$ of latania scale reached full development between larva and adult with a $56 \%$ survival rate (Table 2). On the contrary, it did not reach full development when fed with individuals of the ${ }^{1 \text { st }} \mathrm{S}$ of latania scale. Furthermore, A. diaspidis completed its developmental cycle significantly faster when fed with $3^{\text {rd }} \mathrm{S}$ of latania scale $(F=32.30, \mathrm{gl}=1, p=0.0001)$ (Table 2). Studies conducted by Opp and Luck (1986) found differences in offspring mortality of A. melinus and $A$. lingnanensis parasitoids at distinct stages of $A$. aurantii scale and with a higher number of $A$. melinus individuals dying in small hosts.

Aphytis melinus has an idiobiont behavior, i.e., it prevents further development of the scale (Heimpel et al., 1997), which also coincides with results for A. diaspidis in this study. The postembryonic developmental period in idiobionts is less than in koinobionts; conversely, they spend more time as adults parasitizing their host (Mayhew and Blackburn, 1999).

Latania scale fed with butternut squash was fully developed from the $1^{\text {st }} \mathrm{S}$ to the $3{ }^{\text {rd }} \mathrm{S}$ with an $84 \%$ survival rate (Table 3 ), which demonstrates that the substrate used for its development was adequate.

Table 2. Postembryonic development of Aphytis diaspidis under laboratory conditions at $26 \pm 2{ }^{\circ} \mathrm{C}, 65 \pm 5 \% \mathrm{RH}$, and 14:10 h (L:D).

\begin{tabular}{lcccccc}
\hline \multirow{2}{*}{$\begin{array}{l}\text { Hemiberlesia } \\
\text { lataniae }\end{array}$} & $\mathrm{n}$ & Larva & Pupa & Adult & $\begin{array}{c}\text { Survival } \\
(\%)\end{array}$ & $\begin{array}{c}\text { Egg to adult (d) } \\
\text { Mean } \pm \text { SEM }\end{array}$ \\
\cline { 3 - 6 } $1^{\text {st } S}$ & 25 & 0 & 0 & 0 & 0 & 0 \\
$2^{\text {nd }} \mathrm{S}$ & 25 & 2 & 2 & 2 & 8 & $21.50 \pm 0.70 \mathrm{a}^{*}$ \\
$3^{\text {rd } \mathrm{S}}$ & 25 & 25 & 14 & 14 & 56 & $19.14 \pm 0.53 \mathrm{~b}$ \\
\hline
\end{tabular}

"Mean on the same row with different letter differs according to Tukey Test $(\mathrm{P} \leq 0.05)$; SEM: standard error of the mean. 
Table 3. Postembryonic development of Hemiberlesia lataniae on Cucurbita moschata under laboratory conditions at $26 \pm 2{ }^{\circ} \mathrm{C}, 65 \pm 5 \%$ RH, and 14:10 h (L:D).

\begin{tabular}{cccccccc}
\hline & & \multicolumn{3}{c}{ Number of . latania } & & Time (d) egg \\
\cline { 3 - 5 } & $\mathrm{n}$ & $1^{\text {st } \mathrm{S}}$ & $2^{\text {nd }} \mathrm{S}$ & $3^{\text {rd }} \mathrm{S}$ & $\begin{array}{c}\text { Survival } \\
(\%)\end{array}$ & $\begin{array}{c}\text { to } 3^{\text {rd }} \mathrm{S} \\
\text { Mean } \pm \text { SEM }\end{array}$ \\
\hline H.lataniae & 25 & 25 & 23 & 21 & 84 & $26.09 \pm 7.34$
\end{tabular}

Mean on the same row with different letter differs according to Tukey Test $(\mathrm{P} \leq 0.05)$; SEM: standard error of the mean.

\section{Life table parameters}

It was observed that latania scale had a higher net reproduction rate $\left(\mathrm{R}_{0}\right)$ and generation time $(\mathrm{T})$, and conversely, lower intrinsic growth rate $\left(\mathrm{r}_{\mathrm{m}}\right)$ and finite growth rate $(\lambda)$ than $A$. diaspidis (Tables 4 and 5).

Parameters show that the A. diaspidis population grows 5.24 times in $16.87 \mathrm{~d}$, i.e., for each female of the current generation, 5.24 females are produced in the following generation. Furthermore, each female on any one day will result in 1.1 females on the next day. Therefore, under favorable conditions, the number of females in the $A$. diaspidis population increases at a daily growth rate that could reach about $10 \%$ (Table 4).

The net reproduction rate, or number of females for each female of a generation, was considerably higher for latania scale than A. diaspidis (Tables 4 and 5), which indicates its high reproductive capacity when fed butternut squash. Moreover, the net reproduction rate obtained for A. diaspidis indicates a low substitution potential for each female having latania scale as a host under laboratory conditions. The oviposition period of A. diaspidis was also lower than for latania scale.

The intrinsic growth rate, defined as a population's capacity to multiply, was higher for A. diaspidis (0.099) than latania scale (0.068) (Tables 4 and 5). These results confirm the potential of $A$. diaspidis to control latania scale, as well as adapting well in field conditions with

Table 4. Life table parameters and statistics related to Aphytis diaspidis parasitizing Hemiberlesia lataniae on butternut squash (Cucurbita moschata) under laboratory conditions at $26 \pm 2{ }^{\circ} \mathrm{C}, 65 \pm 5 \% \mathrm{RH}$, and 14:10 h (L:D).

\begin{tabular}{lcc}
\hline Parameter & $\mathrm{n}$ & $\begin{array}{c}\text { Jackknife estimated from life } \\
\text { table parameters }(95 \% \mathrm{CI})\end{array}$ \\
\hline Intrinsic growth rate $\left(\mathrm{r}_{\mathrm{m}}\right)$ & 25 & $0.09(0.08-0.12)$ \\
Net reproductive rate $\left(\mathrm{R}_{0}\right)$ & 25 & $5.24(3.13-7.35)$ \\
Generation time $(\mathrm{T})$ & 25 & $16.87(16.79-16.96)$ \\
Finite growth rate $(\lambda)$ & 25 & $1.10(1.08-1.13)$ \\
\hline
\end{tabular}

Table 5. Life table parameters and statistics related to Hemiberlesia lataniae on butternut squash (Cucurbita moschata) under laboratory conditions at $26 \pm 2{ }^{\circ} \mathrm{C}, 65 \pm 5 \% \mathrm{RH}$, and 14:10 h (L:D).

\begin{tabular}{lcc}
\hline Parameter & $\mathrm{n}$ & $\begin{array}{c}\text { Jackknife estimated from life } \\
\text { table parameters }(95 \% \mathrm{CI})\end{array}$ \\
\hline Intrinsic growth rate $\left(\mathrm{r}_{\mathrm{m}}\right)$ & 25 & $0.068(0.06-0.07)$ \\
Net reproductive rate $\left(\mathrm{R}_{0}\right)$ & 25 & $139.86(90.71-189.02)$ \\
Generation time $(\mathrm{T})$ & 25 & $72.35(69.81-74.89)$ \\
Finite growth rate $(\lambda)$ & 25 & $1.07(1.06-1.076)$ \\
\hline CI: Confidence interval. & &
\end{tabular}

plum trees in the Limache zone where it is commonly attacked by $Q$. perniciosus, according with "unpublished data". Although the $r_{m}$ parameter was obtained under laboratory conditions, it is a fundamental indicator of the potential of parasitoids to control their hosts (Stenseng et al., 2003; Vargas et al., 2005) and suggests that the population reduction pattern could be maintained under field conditions, which represents a significant factor in regulating latania scale populations. However, this characteristic must be compared with that of other species such as A.melinus, A. chilensis, A. hispanicus, and Encarsia sp. that can use the same field substrate. Studies carried out by Borer (2002) point out that there is interspecific competition between A. melinus and Encarsia perniciosi, which are both $A$. aurantii parasitoids (Maskell), so that the success of biological control in the field could also be conditioned by other species.

The finite growth rate was similar for both species and corresponded to 1.1 for A. diaspidis and 1.08 for $H$. lataniae (Tables 4 and 5). These data indicate that the parasitoid tends to generate a slightly higher number of individuals per day, which is an advantage if analyzed as a potential biological control agent because it could maintain the latania scale population at a low level.

Generation time, the mean time between two successive generations, proved to be significantly higher in latania scale (72.34) (Tables 4 and 5) and is interpreted as an advantage for increasing the parasitoid population (La Rossa et al., 2002).

On the other hand, since life table parameters can vary depending on the different species breeds (Stenseng et al., 2003; Liu, 2007), it is essential to have an exact classification through molecular characterization. This technique is highly effective to correctly identify parasitoids and Diaspididae (Pinto et al., 2002; Morse and Normark, 2006). Complementary to this, applying predictive models through population growth simulation that considers abiotic mortality factors, alternative food consumption, and migrational or competitive shifts (Flores et al., 2001; Barron, 2007; Gutierrez et al., 2008) will allow to determine the most biologically adequate parasitoid on latania scale for subsequent massification and release in affected crops.

\section{CONCLUSIONS}

Aphytis diaspidis reached the highest parasitoidism rate when the $3^{\text {rd }} \mathrm{S}$ of latania scale was used, whereas no parasitoidism was recorded when $H$. lataniae individuals from the $1^{\text {st }} \mathrm{S}$ were provided. In the same way, it completes its development from egg to adult in this stage and has a $56 \%$ survival rate. Therefore, in field releases, successful scale control will occur mainly the $3^{\text {rd }} \mathrm{S}$ prevails.

Latania scale had a higher net reproduction rate $\left(\mathrm{R}_{0}\right)$ and generation time $(\mathrm{T})$, but a lower intrinsic growth rate $\left(r_{\mathrm{m}}\right)$ and finite growth rate $(\lambda)$ than $A$. diaspidis. 
The parasitoid had a higher intrinsic growth rate, lower generation time, and the capacity to produce a higher number of individuals per day than $H$. lataniae, which indicates a high potential of the parasitoid as a biological control agent under field conditions.

\section{ACKNOWLEDGEMENTS}

We wish to acknowledge the FONDEF D03I1077 and FONTAGRO FTG-32/03 projects that financed part of this study, the Comité de la Palta Hass for facilitating access to its members' crops where the material for this study was extracted, the CREAS (Centro Regional de Estudios de Alimentos Saludables) for its sponsorship, to the professionals Renato Ripa and Sharon Rodríguez, and especially to support staff Antonieta Cardemil and Alejandrina Ubillo for their collaboration. Finally, special thanks to Paulina Bermúdez for her thorough revision of the manuscript.

Tasa de parasitoidismo y parámetros de tabla de vida de Aphytis diaspidis (Howard) (Hymenoptera: Aphelinidae) y Hemiberlesia lataniae (Signoret) (Hemiptera: Diaspididae). La escama latania, Hemiberlesia lataniae (Signoret), se ha transformado en Chile en una plaga de importancia primaria en palto (Persea americana Mill.), donde alcanza altas poblaciones en la fruta debido al escaso control natural existente. El objetivo del presente estudio fue conocer parámetros biológicos del parasitoide Aphytis diaspidis (Howard), como agente de control de la escama latania. Es así como se determinó en laboratorio el desarrollo postembrionario, tasa de parasitoidismo, y parámetros de tabla de vida del parasitoide y la escama. El desarrollo postembrionario y la tasa de parasitoidismo de A. diaspidis varió significativamente al ser evaluado sobre distintos estadios de la escama latania, alcanzando el mayor porcentaje de supervivencia (56\%) sobre el tercer estadio de la escama, así como el menor tiempo de desarrollo entre huevo y adulto (19,14 d) y la máxima tasa de parasitoidismo $(66 \%)$. La tasa intrínseca de crecimiento $\left(\mathrm{r}_{\mathrm{m}}\right)$ fue mayor para $A$. diaspidis $\left(\mathrm{r}_{\mathrm{m}}=0,099\right)$ que la de escama latania $\left(\mathrm{r}_{\mathrm{m}}=0,068\right)$. Estos resultados de laboratorio muestran que $A$. diaspidis es un parasitoide eficaz en disminuir las poblaciones de $H$. lataniae, cuando prevalece el tercer estadio.

Palabras clave: Desarrollo postembrionario, tablas de vida, parasitoidismo, control biológico, escama blanca, palto.

\section{LITERATURE CITED}

Apostolos, P.,A.Aguilar,A. Tena, and F. Garcia-Marí. 2010. Influence of host size on parasitism by Aphytis chrysomphali and A. melinus (Hymenoptera: Aphelinidae) in Mediterranean populations of California red scale Aonidiella aurantii (Hemiptera: Diaspididae). Biological Control 55:132-140.
Barron, M. 2007. Retrospective modelling indicates minimal impact of non-target parasitism by Pteromalus puparum on red admiral butterfly (Bassaris gonerilla) abundance. Biological Control 41:53-63.

Bermúdez, P., R. Vargas, C. Cardemil, and E. López. 2010. Effect of pollen from different plant species on development of Typhlodromus pyri (Sheuten) (Acari: Phytoseiidae). Chilean Journal of Agricultural Research 70:408-416.

Bernal, J., R. Luck, and J. Morse. 1999. Host influences on sex ratio, longevity, and egg load of two Metaphycus species parasitic on soft scales: implications for insectary rearing. Entomologia Experimentalis et Applicata 92:191-204.

Bernardo, U., G. Viggiani, and R. Sasso. 2005. Biological parameters of Thripobius semiluteus Boucek (Hym. Eulophidae) a larval endoparasitoide of Heliothrips haemorrhoidalis (Bouché) (Thysan. Thripidae). Journal of Applied Entomology 129:250-257.

Bezemer, T.M., J.A. Harvey, and N.J. Mills. 2005. Influence of adult nutrition on the relationship between body size and reproductive parameters in a parasitoid wasp. Ecological Entomology 30:571580.

Blank, R.H., G.S.C. Gill, and J.M. Kelly. 2000. Development and mortality of greedy scale (Homoptera: Diaspididae) at constant temperatures. Environmental Entomology 29:934-942.

Borer, E.T. 2002. Intraguild predation in larval parasitoids: implications for coexistence. Journal of Animal Ecology 71:957965.

Burger, J.M.S., T.M. Reijnen, J.C. Van Lenternen, and L. Vet. 2004. Host feeding in insect parasitoids: why destructively feed upon a host that excretes an alternative? Entomologia Experimentalis et Applicata 112:207-215.

Charles, J., and R. Henderson. 2002. Catalogue of the exotic armoured scale insects (Hemiptera:Coccoidea: Diaspididae) in New Zealand. Journal of the Royal Society of New Zealand 32:587-615.

Chi, H., and T. Yang. 2003. Two-sex life table and predation rate of Propylaea japonica Thunberg (Coleoptera: Coccinellidae) fed on Myzus persicae (Sulzer) (Homoptera: Aphididae). Environmental Entomology 32:327-333.

Claps, L.E., V.R. Wolff, and R.H. González. 2001. Catálogo de las Diaspididae (Hemiptera: Coccoidea) exóticas de la Argentina, Brasil y Chile. Revista de la Sociedad Entomológica Argentina 60:9-34.

Collier, T.R. 1995. Host feeding, egg maturation, resorption, and longevity in the parasitoid Aphytis melinus (Hymenoptera: Aphelinidae). Annals of the Entomological Society of America 88:206-214

Eliopoulos, P. 2006. Life tables of Venturia canescens (Hymenoptera: Ichneumonidae) parasitizing the Mediterranean flour moth (Lepidoptera: Pyralidae). Journal of Economic Entomology 99:237-243

Erler, F., and I. Tunç. 2001. A survey (1992-1996) of natural enemies of diaspididae species in Antalya, Turkey. Phytoparasitica 29:299305.

Flores, J., J. Mena, and R. Vargas. 2001. Computational model for a biological pest control of the "Falsa arañita de la vid". 10 $0^{\text {th }}$ Latin Congress of Bio-Mathematics and $5^{\text {th }}$ Congress in Math-Ecology. October 29 to November 11. Campinas, Sao Paulo, Brazil.

Giron, D., S. Pincebourde, and J. Casas. 2004. Lifetime gains of host-feeding in a synovigenic parasitic wasp. Physiological Entomology 29:436-442.

Giron, D., A. Rivero, N. Mandon, E. Darrouzet, and J. Casas. 2002. The physiology of host feeding in parasitic wasps: implication for survival. Functional Ecology 16:750-757.

Gutierrez, A.P., K.M. Daane, L. Ponti, V.M. Walton, and C.K. Ellis. 2008. Prospective evaluation of the biological control of vine mealybug: Refuge effects and climate. Journal of Applied Ecology 45:524-536.

Hansen, L., and K. Jensen. 2002. Effect of temperature on parasitism and host-feeding of Thrichogramma turkestanica (Hymenoptera: Trichogrammatidae) on Ephestia kuehniella (Lepidoptera: Pyralidae). Journal of Economic Entomology 95:50-56. 
Heimpel, G.E., and J.A. Rosenheim. 1995. Dynamic host feeding by the parasitoid Aphytis melinus: the balance current and future reproduction. Journal of Animal Ecology 64:153-167.

Heimpel, G.E., J.A. Rosenheim, and D. Kattari. 1997. Adult feeding and lifetime reproductive success in the parasitoid Aphytis melinus. Entomologia Experimentalis et Applicata 83:305-315.

Japoshvili, G., and I. Karaca. 2002. Coccid (Homoptera: Coccoidea) species of Isparta Province, and their parasitoids from Turkey and Georgia. Turkish Journal of Zoology 26:371-376.

La Rossa,F., D. Crespo, and R. Lecuona. 2002. Population parameters of Spalangia endius Walker (Hymenoptera: Pteromalidae) on pupae of Musca domestica L. (Diptera: Muscidae). Neotropical Entomology 31:597-600.

Liu, T.X. 2007. Life history of Eretmocerus melanoscutus (Hymenoptera: Aphelinidae) parasitizing nymphs of Bemisia tabaci Biotype B (Homoptera: Aleyrodidae). Biological Control 42:77-85.

López, E., and P. Bermúdez. 2007. Las plagas del palto en Chile: Aspectos relevantes de su biología, comportamiento y manejo 104 p. Ediciones Universitarias de Valparaíso, Valparaíso, Chile.

Maia, A., A.J. Luiz, and C. Campanhola. 2000. Statistical inference on associated fertility life table parameters using Jackknife technique: computational aspects. Journal of Economic Entomology 93:511-518.

Matadha, D., G.C. Hamilton, and J.H. Lashomb. 2004. Effect of temperature on development, fecundity, and life table parameters of Encarsia citrina Craw (Hymenoptera: Aphelinidae), a parasitoid of Euonymus Scale, Unaspis euonymi (Comstock), and Quadraspidiotus perniciosus (Comstock) (Homoptera: Diaspididae). Environmental Entomology 33:1185-1191.

Matsumoto, T., T. Itioka, T. Nishida, and T. Inoue. 2003. Introduction of parasitoids has maintained a stable population of arrowhead scales at extremely low levels. Entomologia Experimentalis et Applicata 106:115-125.

Mayhew, P.J., and T.M. Blackburn. 1999. Does development mode organize life-history traits in the parasitoids Hymenoptera? Journal of Animal Ecology 68:906-916.

Mazzeo, G., S Longo, D. Benfatto, V. Palmeri, and A. Leo. 2001. Trials of biological control of Aonidiella aurantii Maskell (Hemiptera, Coccoidea) in citrus groves in Italy. Bollettino di Zoologia Agraria e di Bachicoltura (Milano) 33:485-488.

Morse, G.E., and B.B. Normark. 2006. A molecular phylogenetic study of armored scale insects (Hemiptera: Diaspididae) Systematic Entomology 31:338-349.

Murdoch, W., C.J. Briggs, and S. Swarbrick. 2005. Host suppression and stability in a parasitoid-host system: Experimental demonstration. Science 309:610-613.

Opp, S.B., and R.F. Luck. 1986. Effects size on selected fitness components of Aphytis melinus and A. lingnanensis (Hymenoptera: Aphelinidae). Annals of the Entomological Society of America 79:700-704.

Pinto, J.D., A.B. Koopmanschap, G.R. Platner, and R. Stouthamer. 2002. The North American Trichogramma (Hymenoptera: Trichogrammatidae) parasitizing certain Tortricidae (Lepidoptera) on apple and pear, with ITS2 DNA characterizations and description of a new species. Biological Control 23:134-142.
Ripa, R., and P. Larral. 2008. Manejo de plagas en paltos y cítricos. Colección Libros INIA N $\mathrm{N}^{\circ} 23.400$ p. Instituto de Investigaciones Agropecuarias (INIA), Centro Regional de Investigación La Cruz, La Cruz, Chile.

Rivero, A., and S.A. West. 2002. The physiological costs of being small in a parasitic wasp. Evolutionary Ecology Research 4:407420 .

Rivero, A., and S.A. West. 2005. The costs and benefits of host feeding in parasitoids. Animal Behavior 69:1293-1301.

Rojas, S. 2005. Control biológico de plagas en Chile, historia y avances. Colección Libros INIA N ${ }^{\circ} 12.123$ p. Instituto de Investigaciones Agropecuarias (INIA), Centro Regional de Investigación La Cruz, La Cruz, Chile.

Rose, M. 1990. Rearing and mass rearing. In D. Rosen (ed.) Armored scale insects: Their biology, natural enemies and control. Vol. A (World crop pests; 4A). Elsevier, Barking, UK.

Rosen, D., and P. De Bach. 1979. Species of Aphytis in the world (Hymenoptera: Aphelinidae). In W. Junk (ed.) Series Entomologica 17. KV Publisher, The Hague, The Netherlands.

Rugman-Jones, P.F., J.G. Morse, and R. Stouthamer. 2009. Rapid molecular identification of armored scale insects (Hemiptera: Diaspididae) on Mexican 'Hass' avocado. Journal of Economic Entomology 102:1948-1953.

SAS Institute. 2007. SAS system for windows 2000. Version 8.2 SAS Institute, Cary, North Carolina, USA.

Speight, M.R., M.D. Hunter, and A.D. Watt. 2000. Ecology of insects: concepts and applications. 350 p. Blackwell Science, Oxford, UK.

Stenseng,L.,H. Skovgard, and P. Holter. 2003. Life table studies of the pupal parasitoid Urolepis rufipes (Hymenoptera: Pteromalidae) on the house fly Musca domestica (Diptera: Muscidae) in Denmark Environmental Entomology 32:717-725.

Vargas, R., N. Olivares, and A. Cardemil. 2005. Postembryonic development and life table parameters of Typhlodromus pyri Scheuten, Cydnodromus californicus (McGregor) (Acarina: Phytoseiidae) and Brevipalpus chilensis Baker (Acarina: Tenuipalpidae). Agricultura Técnica 65:147-156.

Vargas, R., y S. Rodríguez. 2008. Escama latania. p. 163-171. In Ripa, R., y P. Larral (eds.) Manejo de plagas en paltos y cítricos. Colección Libros INIA $\mathrm{N}^{\circ}$ 23. Instituto de Investigaciones Agropecuarias (INIA), Centro Regional de Investigación La Cruz, La Cruz, Chile.

Wanner, H., H. Gu, and S. Dorn. 2006. Nutritional value of floral nectar sources for flight in the parasitoid wasp, Cotesia glomerata. Physiological Entomology 31(2):127-133.

Zhang, G., O. Zimmermann, and S.A. Hassan. 2004. Pollen as a source of food for egg parasitoids of the genus Trichogramma (Hymenoptera: Trichogrammatidae). Biocontrol Science and Technology 14:201-209. 